\title{
Combined biotic stresses trigger similar transcriptomic responses but contrasting resistance against a chewing herbivore in Brassica nigra
}

\author{
Christelle Bonnet ${ }^{1}$, Steve Lassueur ${ }^{1}$, Camille Ponzio² ${ }^{2}$ Rieta Gols², Marcel Dicke ${ }^{2}$ and Philippe Reymond ${ }^{1 *}$ (D)
}

\begin{abstract}
Background: In nature, plants are frequently exposed to simultaneous biotic stresses that activate distinct and often antagonistic defense signaling pathways. How plants integrate this information and whether they prioritize one stress over the other is not well understood.

Results: We investigated the transcriptome signature of the wild annual crucifer, Brassica nigra, in response to eggs and caterpillars of Pieris brassicae butterflies, Brevicoryne brassicae aphids and the bacterial phytopathogen Xanthomonas campestris pv. raphani (Xcr). Pretreatment with egg extract, aphids, or Xcr had a weak impact on the subsequent transcriptome profile of plants challenged with caterpillars, suggesting that the second stress dominates the transcriptional response. Nevertheless, P. brassicae larval performance was strongly affected by egg extract or Xcr pretreatment and depended on the site where the initial stress was applied. Although egg extract and $X c r$ pretreatments inhibited insect-induced defense gene expression, suggesting salicylic acid (SA)/jasmonic acid (JA) pathway cross talk, this was not strictly correlated with larval performance.

Conclusion: These results emphasize the need to better integrate plant responses at different levels of biological organization and to consider localized effects in order to predict the consequence of multiple stresses on plant resistance.
\end{abstract}

Keywords: Brassica nigra, Brevicoryne brassicae, Combined stresses, Herbivory, Pieris brassicae, Transcriptome, Xanthomonas campestris pv. raphani (Xcr)

\section{Background}

Biotic and abiotic stresses impose a strong pressure on plants in nature. When combined, stresses such as heat, drought or high light intensity have profound effects on crop performance and yields [1]. Plants have developed specific mechanisms to precisely detect environmental changes and respond to complex stress conditions to minimize damage and conserve sufficient resources for growth and reproduction. Over the years, research has focused mainly on responses to a single stress in several

\footnotetext{
* Correspondence: Philippe.Reymond@unil.ch

${ }^{1}$ Department of Plant Molecular Biology, University of Lausanne, Biophore Building, 1015 Lausanne, Switzerland

Full list of author information is available at the end of the article
}

model plants including Arabidopsis [2-5]. However, there is a growing recognition for the need to consider the effects of multiple stresses at the molecular level and at higher levels of biological organization [6-9]. Such an approach is crucial as we need to know how plants adapt to novel environmental factors in the context of co-occurring stresses [10].

Insect herbivory is a major biotic stress under natural conditions. Therefore, plants have evolved sophisticated constitutive and inducible defenses to resist or reduce the effects of insect attack [11]. Several studies have shown that plants subjected to abiotic stress or nutritional limitation differentially affect the performance and behavior of insects [12-17]. In addition to insects, plant 
pathogens are a major threat to plant growth and survival, but also impact on the colonization by and performance of herbivores feeding on pathogen-infected plants $[18,19]$. As biotrophic and necrotrophic phytopathogens exhibit distinct infection pathways, they induce different plant responses [20]. Their effects on plants may influence the phytochemical environment of the insect attacker in different ways. Moreover, pathogen effects on plant resistance to insects will depend on the biology of the herbivore, e.g., whether it is a phloem feeder or a chewing larva [19]. For example, the necrotrophic pathogen Botrytis cinerea inhibited the development, fecundity and survival rate of the aphid Aphis fabae in Vicia faba, whereas the biotrophic fungus Uromyces viciae-fabae enhanced aphid performance [21]. Most interestingly, the effect of combined B. cinerea and $U$. viciae-fabae stress on aphid performance seemed to fluctuate depending on the order of infection [21]. In contrast, B. cinerea pretreatment had no significant effect on further performance of Pieris rapae caterpillars in Arabidopsis [22]. Tomato plants challenged by Pseudomonas syringae reduced Spodoptera exigua growth, whereas tomato mosaic virus increased caterpillar performance but decreased aphid colonization [23]. Manduca sexta larvae feeding on Nicotiana attenuata plants treated with the bacterial quorum-sensing $N$-acylhomoserine lactone were significantly heavier than on untreated plants. This effect was attributed to an inhibition of plant defenses against herbivores [24]. Oviposition by Pieris brassicae inhibited growth of $P$. syringae strains in Arabidopsis [25]. Furthermore, P. brassicae larvae showed a poor performance on $P$. syringae-infected Arabidopsis plants, suggesting that insect eggs inhibit plant defenses for the benefit of their progeny [25]. In summary, the outcome of a biotic pretreatment on herbivore performance is difficult to predict and depends primarily on the severity and duration of the infection, attack strategies of the pathogens and herbivores involved, and the plant species that is attacked.

Induced defenses are controlled by phytohormones. Biotrophic pathogens, which obtain nutrients from living tissues activate mainly the salicylic acid (SA) pathway, while necrotrophs obtaining nutrients from dead host tissues and chewing herbivores activate especially the jasmonic acid (JA) and ethylene (ET) pathways [26]. These pathways regulate the expression of defense genes that provide specific resistance to the attacker. The existence of antagonism between the SA and JA pathways is well established [26]. It is thought to modulate prioritization of defense allocation towards different attackers [27, 28] but is also the target of defense manipulation by plant pathogens and insect herbivores [26, 29-33]. Stimulation of the SA pathway attenuated plant response to generalist herbivores, i.e. herbivores feeding on plant species in different plant families, but had no effect on the specialist $P$. brassicae, which primarily feeds on plant species within the Brassicaceae family $[34,35]$. At the molecular level, treatments with SA or pathogens that enhance SA levels reduced the expression of the antiherbivore VSP2 in Arabidopsis [36, 37]. Pathway cross talk may thus represent a crucial component of plant responses to combined stresses.

Transcriptome analyses have been conducted to better understand plant responses to multiple stresses. For instance, one study analyzed transcriptomic differences in ten ecotypes of Arabidopsis challenged by single or dual (a) biotic stress combinations. The authors concluded that the majority of changes in gene regulation in response to combined stresses were not predictable using expression profiles from single treatments [38]. Drought or flooding pretreatment significantly modified the transcriptome signature of Solanum dulcamara plants infested with $S$. exigua [16]. Simultaneous attack by sapfeeding and chewing herbivores in $N$. attenuata triggered a transcriptional response that was distinct from those in response to single attackers [39]. An overview of 33 different combined stresses revealed that each treatment seems to generate a unique response, reflecting the plant's ability to specifically adapt to a changing and complex environment [8]. The same conclusion was reached for the impact of combined stresses at the metabolomic and proteomic level, with several unique metabolites and proteins accumulating after multiple stresses but not after single stresses $[8,40]$. However, Arabidopsis plants challenged by both nematodes and drought responded primarily to drought [41].

Thus, plant responses to multiple stresses are interconnected and result in complicated and unpredictable outcomes. More studies on plant responses to combined stress conditions are critical to understand the effects of these interactions. This requires analysis at multiple levels, transcriptional and hormonal responses, defense compound accumulation and ecological consequences, using different plant species. Here, we investigated the effects of combined biotics stresses on plant transcriptomic changes, changes in plant hormones and metabolites and insect performance, using and ecologically relevant system. We selected the wild annual crucifer, Brassica nigra, subjected to feeding by a naturally associated lepidopteran pest, caterpillars of the large cabbage white $P$. brassicae, alone or in combination with a second stress. Combined stresses consisted of a pretreatment with $P$. brassicae egg extract, the cabbage aphid Brevicoryne brassicae, or the necrotrophic bacterial phytopathogen Xanthomonas campestris pv. raphani (Xcr), followed by caterpillar herbivory. All stresses used here occur naturally on B. nigra in the field [42, 43]. Whereas 
plant defenses against chewing larvae are primarily regulated by the JA pathway, eggs and aphids activate primarily the SA pathway [35, 44-46], and defense against $\mathrm{Xcr}$ is mediated by SA, JA and ET [47]. Given the known mutual antagonistic actions of these signaling pathways, we were expecting significant effects of a primary stress on the responses to $P$. brassicae larvae. Interactions of $B$. nigra-attacker interactions are well-investigated at the ecological level under field conditions where multiple attackers occur [43, 48, 49]. However, much less is known about the mechanistic aspects of the responses of $B$. nigra plants to single as compared to combined stresses. This is the topic of the present study.

\section{Results}

Effect of combined stresses on transcriptional responses to herbivory

We used whole-genome Arabidopsis CATMA microarrays $[50,51]$ to assess gene expression changes in $B$. nigra. Previous studies have shown that Arabidopsis microarrays can be successfully used to study transcriptional responses of Brassica oleracea or B. nigra [52, 53]. After 1 day of feeding by $P$. brassicae larvae on B. nigra, 218 genes were significantly upregulated $\left(\log _{2}>0.585\right.$, $P<0.05)$ and 49 genes were significantly downregulated $(\log 2>-0.585, P<0.05)$ (Additional file 1: Table S1). Gene ontology $(\mathrm{GO})$ search of the upregulated genes revealed a highly significant enrichment of terms including response to wounding (GO:0009611), response to stress (GO:0006950), response to jasmonic acid stimulus (GO:0009753), response to biotic stimulus (GO:0009607), response to chitin (GO:0010200), defense response (GO:0006952), jasmonic acid biosynthesis (GO:0009695), oxylipin biosynthesis (GO:0031408), secondary metabolic process (GO:0019748). Downregulated genes were enriched in terms like photosynthesis (GO:0015979), cellular metabolic process (GO:0044237), nitrogen metabolism (GO:0034631, GO:0044271), chloroplast (GO:0005907, GO:0044434) (Additional file 2: Table S2). This transcriptional signature confirms results from previous studies on the response to caterpillar herbivory in other plant species, which have identified a crucial role for the jasmonate pathway in inducing anti-insect defense genes and observed a downregulation of photosynthesis-related genes [45, 54-59]. Because we used Arabidopsis microarrays, some more distantly related $B$. nigra defense genes may have been missed in the hybridization procedure. A more exhaustive list of insect-responsive genes will await transcriptome analyses by RNA sequencing once a $B$. nigra reference genome is available.

Then, to investigate how a biotic pretreatment may affect $P$. brassicae-induced transcriptome changes, we challenged $B$. nigra plants with $P$. brassicae egg extract, the bacterial pathogen $X c r$, or $B$. brassicae aphids before adding $P$. brassicae larvae for $24 \mathrm{~h}$. As control experiments, we subjected $B$. nigra plants to each single stress. Strikingly, an expression-based clustering analysis of all experiments showed that transcriptomes from the three combined stress treatments were grouped with the transcriptome of $P$. brassicae larval treatment, whereas transcriptomes from egg extract, the bacterial pathogen, or aphid single treatments were clearly separated (Fig. 1a). Indeed, from the list of 218 uregulated and 49 downregulated genes after herbivory alone, 206 (94\%), repectively 43 $(88 \%)$, were still similarly regulated after egg extract pretreatment, 155 (72\%), respectively 38 (78\%), after pathogen pretreatment, and 201 (92\%), respectively 46 (94\%), after aphid pretreatment, indicating that the biotic pretreatments applied had a weak effect on the subsequent transcriptional response to herbivory (Fig. 1b, c). Analysis of the 50 top up- and downregulated genes after single treatment with caterpillars showed that expression of 48, respectively 42 genes, did not differ significantly between single or combined stress with egg extract. Similarly, 36 upregulated and 46 downregulated genes were not expressed differently between herbivory and combined stress with aphids (Additional files 3, 4: Figures S1, S2). However, in the case of pathogen pretreatment, 22 of the top-50 genes showed a significantly reduced induction, including known JA-regulated genes like LOX3, CORI3, and $O P R 3$, suggesting that bacterial infection inhibits defense against herbivory (Additional file 3: Figure S1).

A combination of stresses may activate genes that are normally not regulated during single stresses. To identify a specific signature of a combined stress, we searched for genes that were significantly induced or repressed only in the three dual-stress treatments (egg extract/caterpillars, pathogen/caterpillars/, or aphids/caterpillars). There were respectively 7,23 , and 52 upregulated genes and 16, 15 and 13 downregulated genes meeting these criteria. Strikingly, a comparison of these combinedstress-specific genes indicated that only one gene was commonly regulated in egg extract/caterpillars and pathogen/caterpillars while other genes were specifically regulated by each combination of stresses (Fig. 2). A GO search of the combined-stress responsive genes did not reveal enrichment of any particular or conserved biological process (Additional files 5, 6: Figures S3, S4). These results indicate that there is no typical transcriptional signature of a combined stress but that each combination activates a relatively small number of additional genes.

\section{Effect of combined stresses on larval performance and plant defense compounds}

Performance of $P$. brassicae caterpillars was also measured in terms of weight gain on plants pretreated with egg extract or the pathogen and on untreated plants. 


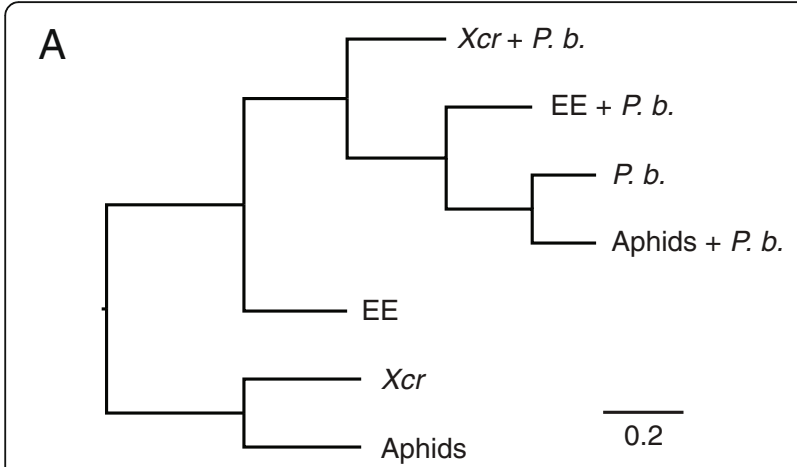

B

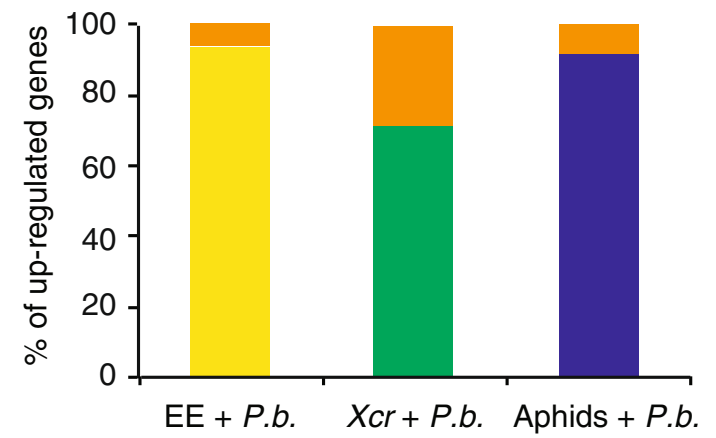

C

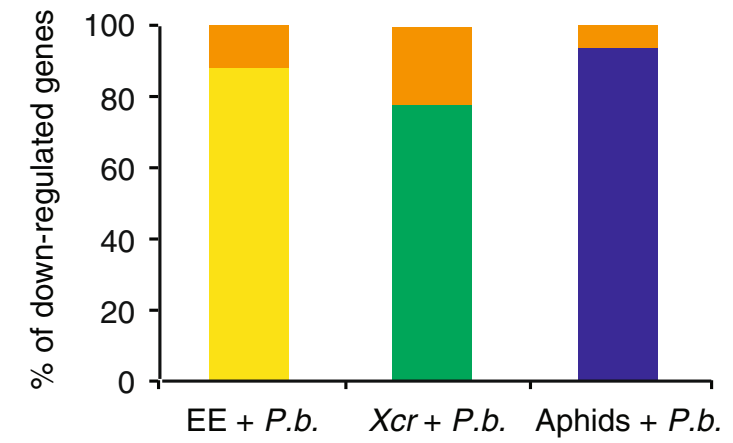

Fig. 1 Expression profiles in response to single and combined stresses in Brassica nigra plants. a Correspondence analysis of expression profiles including all induced or repressed genes in at least one experiment $\left(-0.585<\log _{2}\right.$ ratio $\left.>0.585, P<0.05, n=961\right)$. Clustering and node length calculations were performed with MultiExperiment Viewer 4.8.1 using Pearson's correlation. b Proportion of $P$. brassicae-upregulated genes that are also upregulated during a combined stress. Each bar segment (yellow, green, blue) represents a different combined stress. The proportion of genes specifically induced by $P$. brassicae is shown in orange. The number of genes regulated by herbivory (upregulated, $n=218$; downregulated, $n=49$ ) is set to $100 \%$. (c) Proportion of P. brassicae-downregulated genes also downregulated during a combined stress. P.b., P. brassicae larvae; EE, P. brassicae egg extract; Xcr, Xanthomonas campestris pv. raphani; Aphids, Brevicoryne brassicae

When caterpillars were feeding freely on entire leaves pre-treated with egg extract or the pathogen, their weight gain was significantly reduced compared to that on control plants (linear mixed model (LMM), $P_{\text {[egg ex- }}$ tract $]=2 * 10^{-16}$ and pathogen, $\left.P_{\text {[pathogen] }}=2^{*} 10^{-8}\right)($ Fig. $3 \mathrm{a})$.
To test whether altered insect performance on pretreated plants correlated with changes in defense signals and metabolites, we quantified SA, JA, and glucosinolate (GS) concentrations. GS are potent defense compounds in brassicaceous plants, effective against generalist insects, that accumulate in response to herbivory [60-64]. However, results from whole-leaf analyses showed that concentrations of JA and total GS were not significantly different in leaves that were pretreated with egg extract or the pathogen followed by caterpillar feeding and in leaves exposed to caterpillar feeding alone (Two-way ANOVA, $P_{[\mathrm{JA}, \text { egg extract }]}=0.62, P_{[\mathrm{JA}, \text { pathogen }]}=0.17, P_{[\mathrm{GS}, \text { egg ex }-}$ tract $\left.]=0.46, P_{[\mathrm{GS}, \text { pathogen }]}=0.41\right)($ Additional file 7 : Figure S5). For SA, the presence or absence of caterpillar feeding did not alter the significant accumulation in response to egg extract or pathogen treatment (Two-way ANOVA, $\left.P_{[\mathrm{SA} \text {, egg extract }]}=0.20, P_{[\mathrm{SA} \text {, pathogen }]}=0.49\right)$ (Additional file 7: Figure S5).

Since the difference in larval performance between untreated and pretreated plants was not easily explained by transcriptomic data, by changes in defense hormonal signaling, or by GS accumulation in whole $B$. nigra leaves, we decided to study the effect of pretreatment relative to the feeding site of the caterpillars. The rationale was that locally induced changes within the leaf may account for the observed effects. Noteworthy, a recent study on maize has reported statistically significant higher concentration of defense metabolites, i.e. 1,4-benzoxazin-3-ones, in young leaves compared to old ones and that this was negatively correlated with insect performance [65]. We modified the experimental design by constraining larvae in clip cages locally or distally, relative to the pretreatment site. Caterpillar weight gain was significantly reduced after egg extract pretreatment, but only when caterpillars were forced to feed on the pretreatment site $\left(\mathrm{LMM}, P_{[\text {local }]}=0.029 ; P_{\text {[distal }]}=0.37\right)$ (Fig. 3b). The effect was similar to the whole-leaf response (Fig. 3a). In contrast, caterpillars performed significantly better on pathogen-pretreated site than on control leaves (LMM, $P=9^{*} 10^{-7}$ ) but their weight was not different when forced to feed distally from the pretreatment site (LMM, $P=0.22$ ), suggesting for instance a local suppression of defenses by bacterial effectors (Fig. 3b). This result was different from the result of the whole-leaf experiment, where caterpillar performance was reduced on pathogen-pretreated leaves (Fig. 3a). Thus, the respective localization of pathogen pretreatment and caterpillar feeding site clearly impacted the effect of the pathogen on insect performance.

To further correlate insect performance and site of treatment with defense compound and signaling hormone accumulation, we quantified SA, JA, and GS concentrations in leaf tissues collected from untreated plants, and from pretreated plants at the site where the 
A

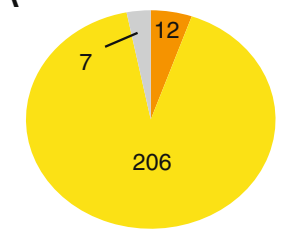

Egg extract $+P$. brassicae

B

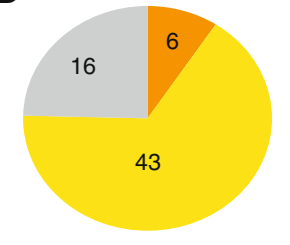

Egg extract $+P$. brassicae

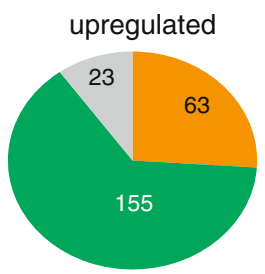

$X c r+P$. brassicae

downregulated

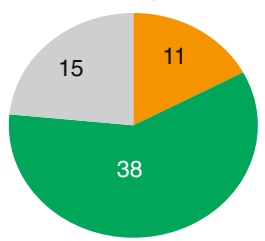

$X c r+P$. brassicae

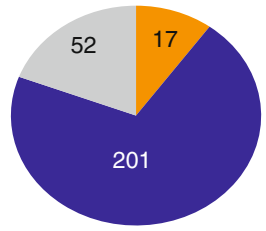

Aphids + P. brassicae

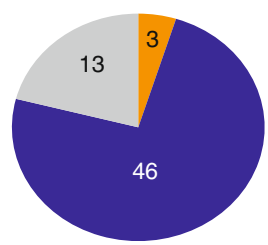

Aphids $+P$. brassicae
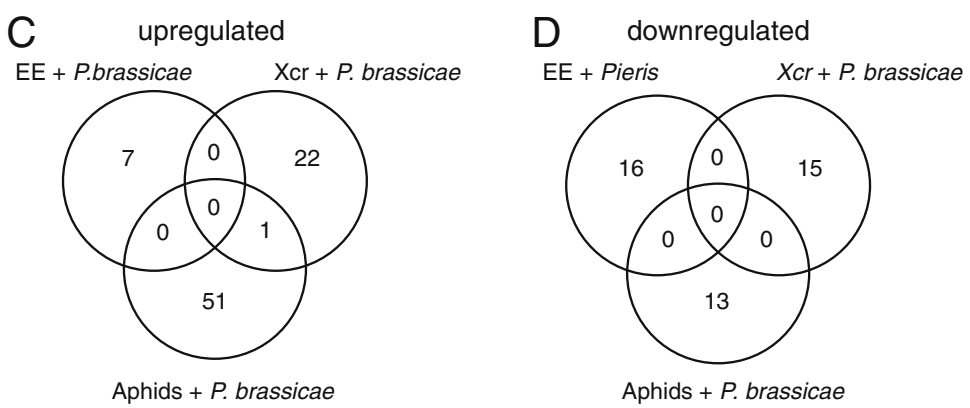

Fig. 2 Number of a upregulated and $\mathbf{b}$ downregulated genes in response to single and combined stresses. Number of genes differentially regulated after combined $P$. brassicae feeding and P. brassicae egg extract (yellow), Xanthomonas campestris pv. raphani (green) and Brevicoryne brassicae (blue) are indicated. Number of genes specifically regulated by $P$. brassicae feeding (orange) and specifically regulated by a combined stress (grey) is also indicated. $\mathbf{c}$, d Distribution of genes specifically regulated by a combined stress shows very little overlap

pretreatment stress was applied. In plants that were also exposed to caterpillar feeding, leaf tissues were collected from the areas where the caterpillars were constrained, so at the site of pretreatment or at a site distal from the pretreatment application (Fig. 4a). In the experiment with egg extract, JA accumulated only in response to herbivory. Egg-extract pretreatment itself did not cause JA accumulation and did not alter caterpillar-induced JA concentration (ANOVA, $F=13,31, P=0.0001$ ) (Fig. 4b). In contrast, pretreatment with the pathogen resulted in a 10-fold increase of JA, whereas JA concentrations in leaf tissues exposed to caterpillar feeding alone were not significantly different from those found in control plants (ANOVA, $F=68.85, P=5^{*} 10^{-7}$ ) (Fig. $4 \mathrm{~b}$ ). JA was induced equally (5-fold) when caterpillars were feeding distally from the site where the pathogen was applied, and when caterpillars were feeding at the same site (Fig. $4 \mathrm{~b}$ ). Egg extract and pathogen pretreatments significantly induced SA, only at the treatment site. Moreover, there was no change in SA concentrations in response to herbivory, and caterpillars did not affect egg extract- or pathogeninduced SA concentrations (ANOVA, $F_{[\text {egg extract }]}=18.37$,
$P_{\text {[egg extract] }}=2 * 10^{-5}, \quad F_{\text {[pathogen] }}=66.18, \quad P_{\text {[patho- }}$ gen] $\left.=5^{*} 10^{-8}\right)($ Fig. 4c). Thus, B. nigra leaves respond locally to biotic challenges by accumulating distinct JA or SA concentrations depending on the biotic stress. Furthermore, the SA response to combined stresses did not differ from the hormonal response to single stresses, whereas it did for JA.

As with whole-leaf experiments, total GS concentrations did not change significantly between control and treated plants $\left(\right.$ ANOVA, $F_{[\text {egg extract }]}=2.71, P_{\text {[egg }}$ extract] $\left.=0.058, F_{[\text {pathogen }]}=0.66, P_{\text {[pathogen }]}=0.68\right)$ (Fig. 4d). Among the 13 glucosinolates that were identified and quantified (Additional file 8: Table S3), sinigrin contributed $91 \%$ to $96 \%$ of the total GS content in different treatments. Consistent with a lack of GS accumulation after biotic stress in B. nigra, we observed that expression of 22 out of 27 GS biosynthesis genes was not significantly enhanced in response to single or combined stresses (Additional files 1, 9: Table S1, Figure S6). This contrasts with the coordinated induction of genes involved in all steps of GS biosynthesis in Arabidopsis after herbivory [64]. 

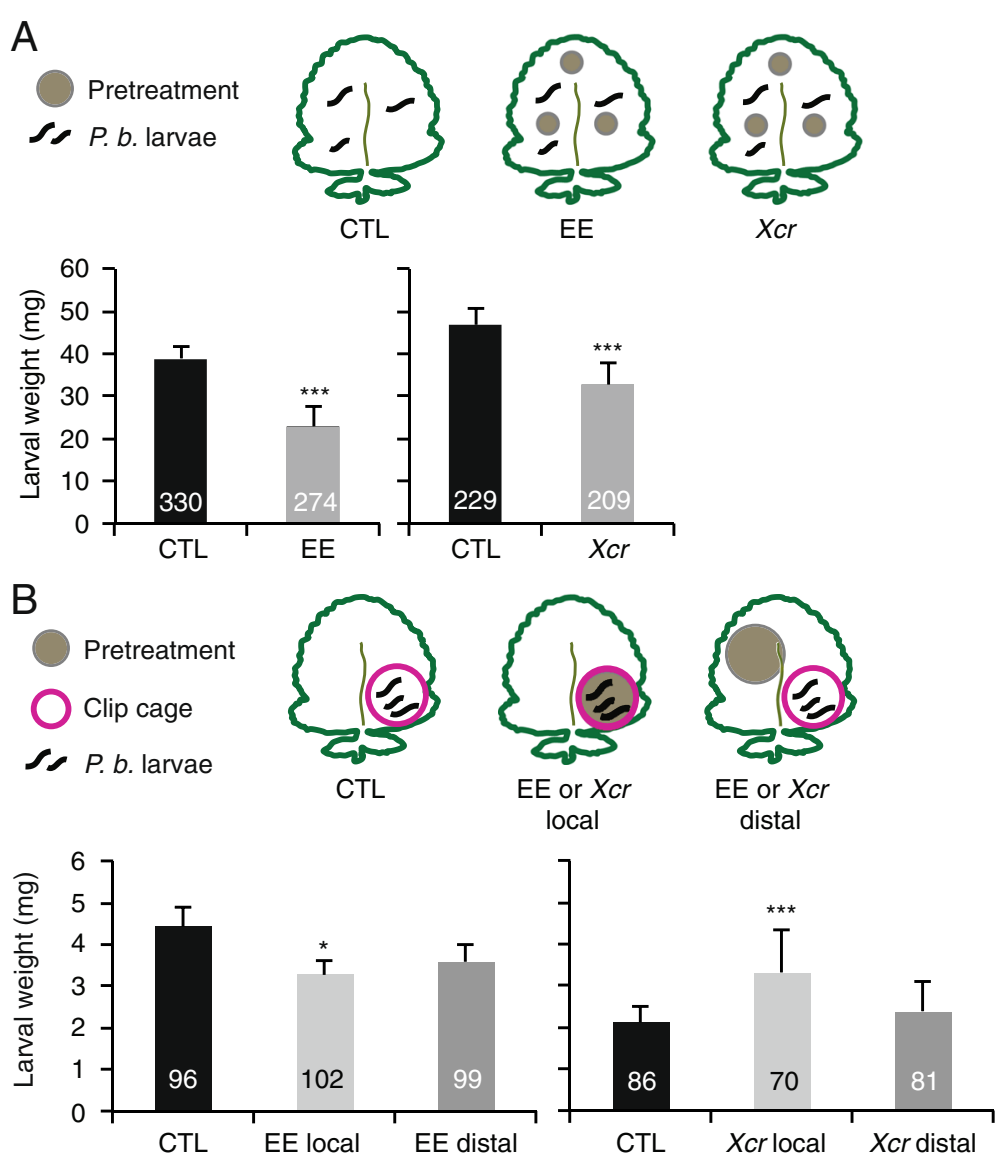

Fig. 3 Impact of pretreatment on insect performance. a Larval weight of P. brassicae feeding on 5-week-old B. nigra plants pretreated for 3 days with P. brassicae egg extract or Xanthomonas campestris pv. raphani (Xcr) was measured after 7 days of feeding. Values ( \pm SE) are the mean of independent experiments ( $P$. brassicae: $C T L / E E, n=5 ; C T L / X C r, n=4)$. The total number of larvae is indicated in each column. Significant differences between control and pretreatment are indicated (linear mixed model, ${ }^{* *} P<0.001$ ). $\mathbf{b}$ Larval weight of $P$. brassicae feeding on 5 -week-old $B$. nigra plants pretreated for 3 days with $P$. brassicae egg extract (EE) or Xanthomonas campestris pv. raphani (XCr) was measured after 4 days. Larvae placed in clip cages were feeding on the treated site (local) or adjacent to the treated site (distal). Values ( \pm SE) are the mean of four (CTL/EE) or three (CTL/XCr) independent experiments. The total number of larvae is indicated in each column. Significant differences between control and pretreatment are indicated (linear mixed model, $\left.{ }^{* * *} P<0.001,{ }^{* *} P<0.01,{ }^{*} P<0.05\right)$

\section{Effect of combined stresses on SA/JA cross talk}

Since exposure to egg extract, pathogen treatment and caterpillar feeding triggered SA and JA accumulation to different extents, we decided to investigate the known SA/JA antagonism in response to combined stresses. We designed QPCR primers for $B$. nigra sequences related to VSP2 and $M Y C 2$, which are JA- and herbivoryregulated genes [56], and for $P R 2$ and $S A G 13$, which are SA- and egg-regulated genes [66]. In single stress treatments, BnVSP2 and BnMYC2 expression were significantly upregulated in tissues exposed to caterpillar feeding, but not in tissues treated with egg extract or the pathogen (Two-way ANOVA, $P_{[\mathrm{VSP} 2 \text {, egg extract }]}=0.01$, $P_{[\text {VSP2, pathogen }]}<0.0001, P_{[\text {MYC2, egg extract }]}=0.04$, $P_{\text {[MYC2, pathogen] }}<0.0001$ ) (Fig. 5). Contrastingly, BnPR2 and BnSAG13 were significantly upregulated in tissues treated with egg extract or the pathogen, but not in tissues exposed to caterpillar feeding (Two-way ANOVA, $P_{[\mathrm{PR} 2 \text {, egg extract }]}<0.0001, P_{[\mathrm{PR} 2 \text {, pathogen }]}<0.0001, P_{\text {[SAG13, egg }}$ extract] $\left.<0.0001, P_{\text {[SAG13, pathogen] }}<0.0001\right)$ (Fig. 5). Interestingly, for combined stresses we found that both egg extract and pathogen pretreatments led to a significantly reduced induction of insect-responsive BnVSP2 and BnMYC2. Combined stresses also reduced the induction of egg extract- or pathogen-responsive BnSAG13, whereas $B n P R 2$ induction was only inhibited by egg extract pretreatment (Fig. 5). These results suggest that under dual-stress conditions a combined accumulation of SA and JA in response to either egg extract or pathogen pretreatment followed by herbivory negatively affects specific JA-and SA-responsive genes. We thus observed a consistent and reciprocal SA/JA cross talk in $B$. nigra, in response to treatment with egg extract or the pathogen followed by caterpillar feeding. 
A
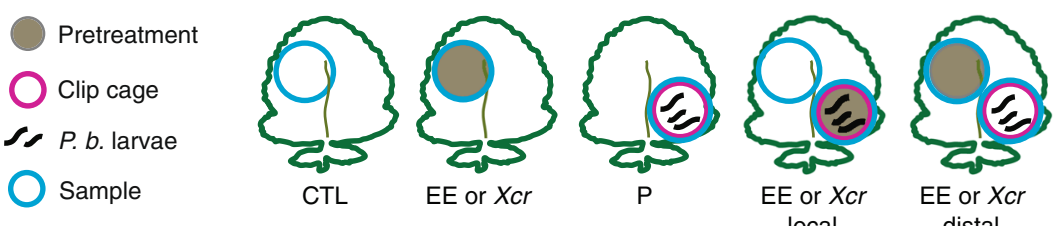

$\mathrm{B}$
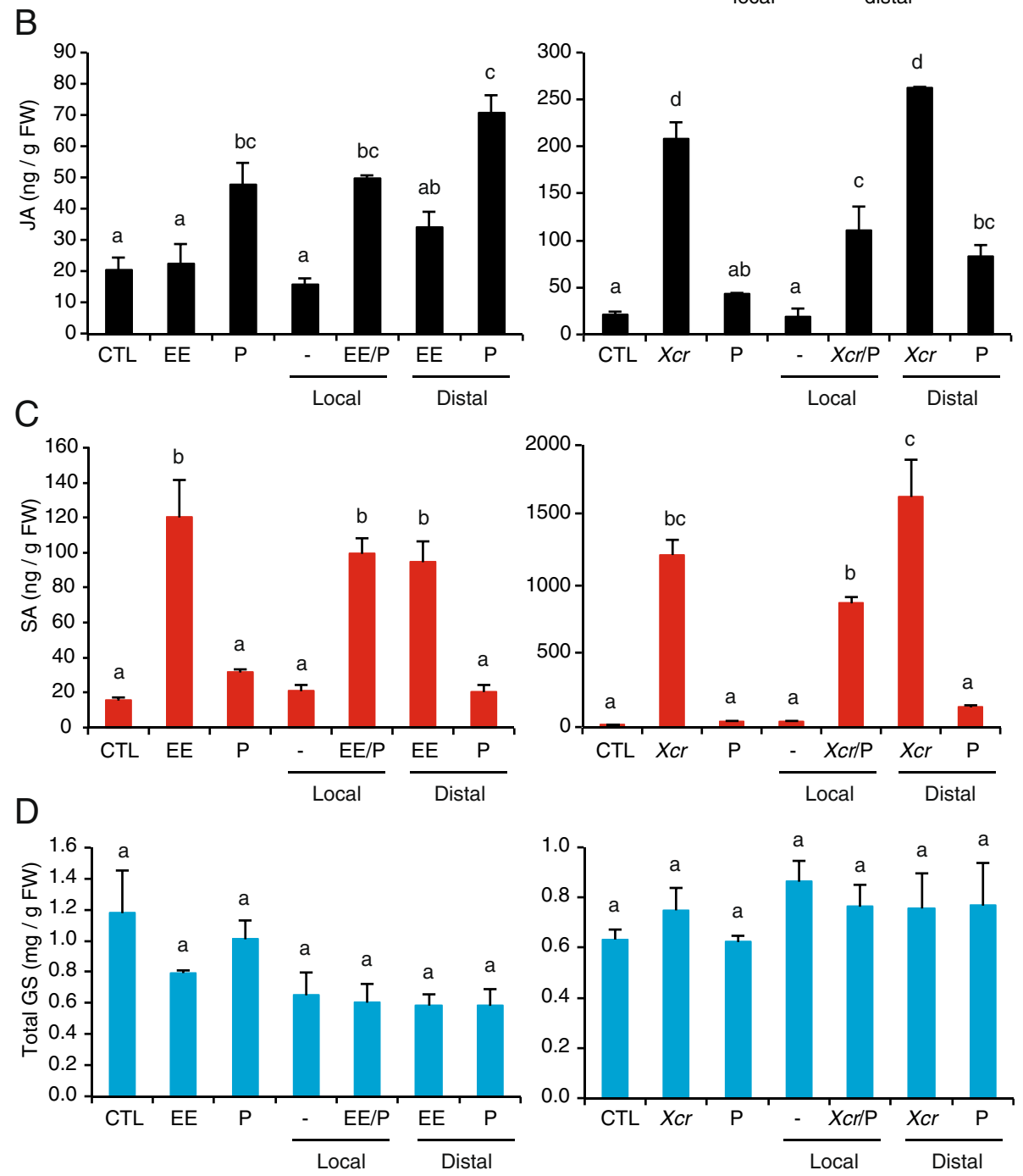

Fig. 4 Quantification of defense signals and glucosinolates. a Experimental design. Quantification of jasmonic acid (JA) b, salicylic acid (SA) c and total glucosinolates (GS) $\mathbf{d}$ in single and combined stress. Leaf discs (blue circle) were collected on 5-week-old B. nigra plants pretreated for 3 days with $P$. brassicae egg extract (EE) or Xanthomonas campestris pv. raphani $\left(X_{C} r\right)$ and further challenged with $P$. brassicae (P) larvae feeding for $24 \mathrm{~h}$ at the site or distal to the site of treatment. Controls consisted of untreated plants (CTL) or plants exposed to a single treatment. -, sample distal from the combined treatment. Values $( \pm$ SE) are the mean of three independent experiments. Letters indicate significant difference between treatments (ANOVA followed by Tukey's honest significant difference test, $P<0.05$ )

\section{Discussion}

Exposure to two or more biotic stresses can either be more detrimental than a single stress or, conversely, have an attenuating effect. The ability of plants to recognize and respond to combined and specific stresses appears thus to be important, especially if stresses, such as pathogens and herbivores, trigger different plant defense pathways. Few studies have been conducted on whole- genome responses under multiple stress conditions, and gene expression studies often focused on the plant model Arabidopsis. Here, B. nigra, which is also a brassicaceous plant species, was used to investigate how plants respond to combined stresses. Surprisingly, transcriptomic responses of $B$. nigra to different pretreatments followed by $P$. brassicae herbivory revealed that the first stress has only a weak impact on transcriptional responses 


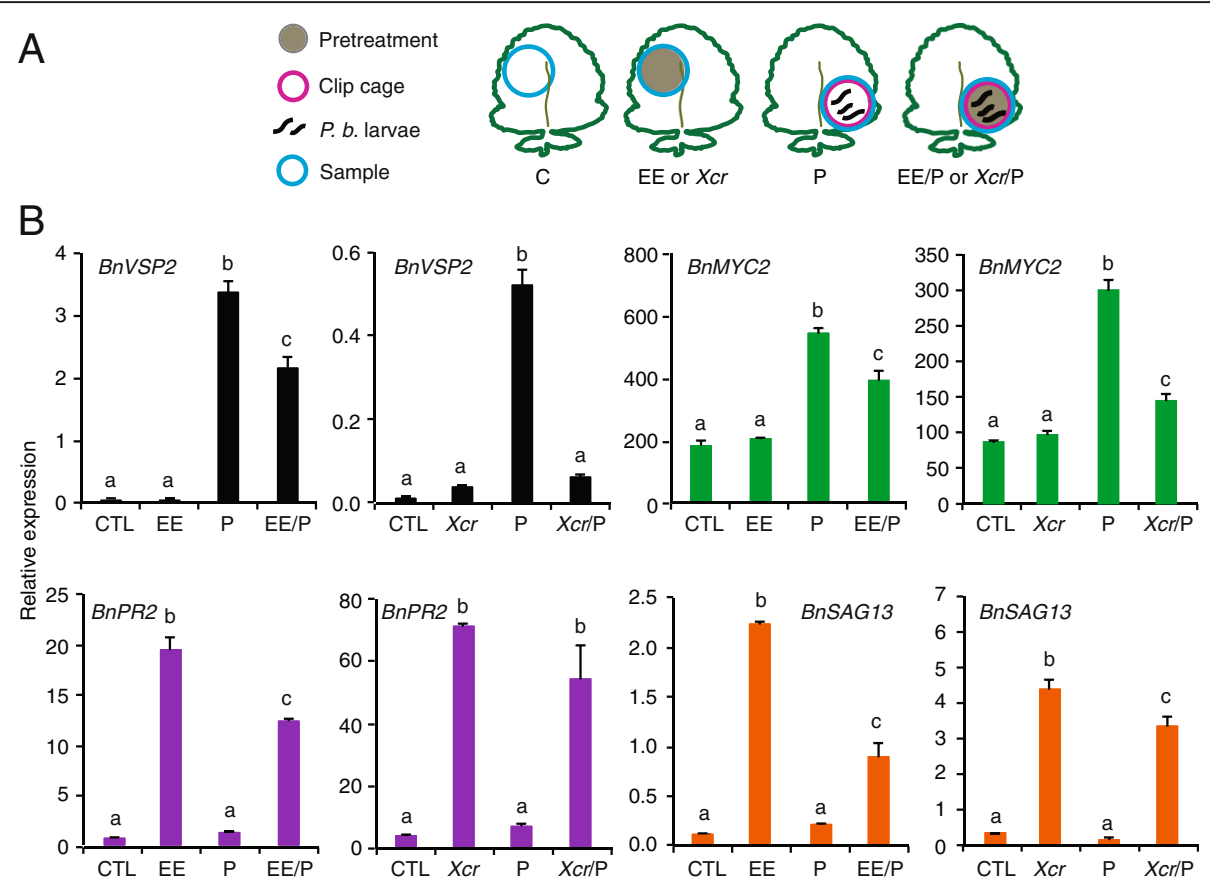

Fig. 5 Expression of JA- and SA-related genes. a Experimental design. $\mathbf{b}$ Expression of B. nigra genes was measured by QPCR and normalized to the housekeeping gene BnSAND. Leaf discs (blue circle) were collected on 5-week-old B. nigra plants pretreated for 3 days with $P$. brassicae egg extract (EE) or Xanthomonas campestris pv. raphani $(X c r)$ and further challenged with P. brassicae (P) feeding for $24 \mathrm{~h}$ at the site of treatment. Untreated plants (CTL) or plants exposed to a single stress were included. Means ( \pm SE) of three technical replicates are shown. These experiments were repeated at least twice with similar results. Different letters indicate significant differences (two-way ANOVA followed by Tukey's honest significant difference test, $P<0.05)$

to the second stress. In addition, no genes common to a combined stress could be identified. It was recently found that the effect of a previous exposure to B. cinerea or to drought only slightly changed Arabidopsis transcriptional response to $P$. rapae feeding, suggesting that plants prioritize a response to the second stress [22]. Similarly, Arabidopsis transcriptome after $P$. brassicae feeding was not affected by pre-exposure to $P$. brassicae eggs, although it was impacted by a cold pretreatment [67]. However, a detailed time-course analysis revealed that pre-exposure shifts the timing of caterpillar-induced responses. Plants responded faster to $P$. rapae if they were preceded by a drought or $B$. cinerea treatment [59], indicating that timing of the response needs to be considered. Atkinson and coworkers [41] postulated that during multiple attack, plants respond preferentially to the most damaging stress (see also [68]). In Arabidopsis challenged by drought and/ or nematodes, $96 \%$ of differentially regulated genes were shared between the combined stress and water stress, whereas only $2 \%$ overlapped with nematode feeding [41]. We hypothesize that $B$. nigra prioritized a response to caterpillar feeding rather than to aphids, eggs or bacteria for the benefit of its own fitness, as $P$. brassicae caterpillars are known to be voracious feeders on brassicaceous plants; these caterpillars are florivorous when reaching the second and subsequent instars, thus reducing fitness directly [69]. Also at the level of the metabolome, changes in $B$. nigra plants exposed to $B$. brassicae aphids and/or P. brassicae caterpillars were the strongest in response to feeding by caterpillars both when feeding alone or together with the aphids on the same leaf [68]. It would be interesting to perform reciprocal experiments to see if the transcriptome of $P$. brassicae-pretreated plants is dominated by the signature of a second biotic stress or if plants prioritize the response to herbivory over other stresses. A recent transcriptome study on Arabidopsis plants infected by Botrytis cinerea with or without prior herbivory suggests that the first hypothesis is more likely [59]. Another testable hypothesis is that plants respond to the most severe stress, irrespective of the order of attack.

We observed that pretreatment with the biotrophic pathogen $X c r$ had a measurable effect on the P. brassicae transcriptome. Indeed, ca. 30\% of insect-induced genes, including JA-regulated genes, were significantly less induced in response to the combined stress, but at the same time weight-gain of $P$. brassicae caterpillars was reduced on pathogen-infected plants when feeding on the entire leaf or when restricted to feed distally from the site where the pathogen-pretreatment was applied. Since $\mathrm{Xcr}$ single treatment triggered SA accumulation, we hypothesize that 
SA/JA cross talk was responsible for this attenuation of gene expression. Our targeted analysis of the JA markers BnVSP2 and BnMYC2 confirmed this observation, but the insect performance assay also indicated that attenuation of these genes does not have negative consequences for plant defense against $P$. brassicae. Caterpillar weight gain was also reduced on plants pretreated with an egg extract. SA-responsive genes, including $P R 1$, were clearly upregulated by egg extract treatment indicating that the SA pathway was activated by eggs, like in Arabidopsis $[35,66]$. This apparent absence of SA/JA cross talk at the whole-genome level may be explained by a relatively less strong response to $P$. brassicae eggs. Indeed, we found a much higher SA accumulation after $X c r$ pathogen than after $P$. brassicae egg extract treatment. In addition, whole-leaf analysis may have diluted a localized response since we detected a localized suppression of BnVSP2 and BnMYC2 expression after egg extract treatment. Cross talk between defense signaling pathways is known to strongly modulate the outcome of combined biotic stresses [26]. Here, we also showed that pathogen and egg extract pretreatments inhibited both induction of JA- and SA-regulated genes in response to additional feeding by $P$. brassicae caterpillars, suggesting that SA/JA cross talk reduced the transcription of some genes considered important in plant defense against insects.

Although single $\mathrm{Xcr}$ infection led to a strong SA and JA accumulation, it is noteworthy that only SA-regulated $B n P R 2$ and BnSAG13 were induced but not JA-regulated BnVSP2 and BnMYC2. Moreover, SA/JA cross talk effects were most pronounced on BnVSP2 and BnMYC2 transcript levels in response to combined $X c r$ /herbivory stresses, indicating that SA strongly influenced the JA pathway in this particular context. Depending on the hormonal context, accumulation of a defense signal is thus not necessarily correlated with the induction of downstream genes. Conversely, pathogen- and eggextract induction of SA-signaling related genes BnPR2 and BnSAG13 was inhibited by caterpillar feeding, suggesting that the reciprocal JA/SA cross talk was also operating. The consequence of such cross talk on susceptibility to $\mathrm{Xcr}$ infection was not tested but would be an interesting topic for future research. Thus, JA and SA activation and their mutualistic antagonistic effects may depend on the strength or the nature of the treatment. For example, a study in Arabidopsis reported a synergistic or antagonistic effect on JA- and SA-induced genes if plants were treated with low or high concentrations of each hormone, respectively [70]. In addition, plant responses to herbivory are known to be dynamic and may depend on the sampling time $[59,71]$. It will thus be interesting in future experiments to see if our observations on SA/JA cross talk at a single time point robustly underlie the outcome of the combined interactions. In conclusion, although the emerging picture is that of a domination of the most recent stress on the transcriptional response [22, 59], it would be interesting to confirm this hypothesis by extending the range of reciprocal combinations of biotic and abiotic stresses, including time-course analyses.

We found that insect performance differed between treatments, suggesting that plant resistance status after combined stresses is difficult to predict based on transcriptome, defense hormone profiles or defense pathway cross talk. Indeed, we observed that insect performance after $P$. brassicae egg-extract application was decreased. In Arabidopsis, we previously showed that $P$. brassicae egg deposition had no effect on performance of the specialist $P$. brassicae [35]. Other studies with Arabidopsis and $B$. nigra revealed that $P$. brassicae performed less well or equally in the presence of eggs, depending on the species identity of the egg donor [67, 72-74]. Similar results were found for $P$. brassicae feeding on other wild brassicaceous species, i.e. Brassica oleracea, Moricandia moricandioides and Sinapsis arvensis exposed to P. brassicae eggs [43]. On the contrary, the generalist S. littoralis performed better on plants already treated with $P$. brassicae egg extract or after natural oviposition [35, 75] but no effect was found for eggs of the generalist Mamestra brassicae on subsequent $M$. brassicae larval performance [72]. Thus, whether insect eggs induce plant defenses is context-specific. Similarly, whether there is an effect of exposure to a biotrophic pathogen is context specific $[25,76]$ and may also depend on the virulence level of the pathogen [77].

Furthermore, $P$. brassicae caterpillars feeding freely on $X c r$-pretreated leaves gained less weight than caterpillars feeding on an untreated leaf. Thus, at the whole-leaf level, $\mathrm{Xcr}$ pretreatment impacted plant defense responses similarly to the egg extract pretreatment, although the underlying mechanism might have been different. A study on Capsicum annuum L. reported an enhanced performance of $S$. exigua larvae on plants infected with $X$. campestris pv. vesicatoria [76]. In contrast, performance of $P$. brassicae larvae was reduced on Arabidopsis infected with Pseudomonas syringae pv. tomato [25]. Again, insect performance on plants infected with phytopathogens seems to be variable.

Surprisingly, compared to whole-leaf bioassays, insect performance assays yielded somewhat contrasting conclusions using clip cages to restrict feeding by caterpillars on specific sites on a leaf. Whereas egg-extract treatment impacted larvae similarly regardless whether they were feeding freely on the whole leaf or locally in a clip cage, $P$. brassicae caterpillars feeding on $\mathrm{Xcr}$-infiltrated leaf area were larger than those constrained to 
feed on a non-infected zone or on an untreated leaf. This observation could be explained by our finding of a local inhibition of JA-dependent defense gene expression after $\mathrm{Xcr}$ pretreatment, although a restricted feeding on egg-extract pretreated tissues did not result in enhanced insect performance. Hence, other factors likely contribute to a localized effect. Xcr infection triggered a local accumulation of both SA and JA while P. brassicae eggextract treatment only triggered SA accumulation. Insect herbivores tend to avoid defended leaf areas [78], which they could not do under the constrained clip-cage conditions. Indeed, when given the choice we noticed that $P$. brassicae larvae avoided egg-treated and $\mathrm{Xcr}$ infected zones (Additional file 10: Figure S7). This is intriguing with regard to the opposite performance of larvae when feeding on egg-treated or Xcr-infected zones. This finding of larval selective feeding deserves further investigation.

Differential activation of the SA and JA signaling pathways may affect metabolite composition. However, we did not observe a differential GS accumulation between treatments. A similar finding was observed after combined ozone and P. brassicae treatment in B. nigra, although larvae grew less well on ozone-pretreated plants [79]. Contrasting results were reported in the study by Ponzio et al. [68] where the total GS concentration significantly increased in response to feeding by $P$. brassicae caterpillars. Furthermore, induction of GS under dual stress conditions with caterpillars and B. brassicae aphids depended on the density of the aphids. The difference in caterpillar densities per leaf, i.e. Thirty in the Ponzio et al. study [68] and 10 here, may explain this discrepancy. As postulated previously [80], other defense compounds may play a crucial role in influencing $P$. brassicae performance on Brassicaceous plant species. The recent identification of flavonoid compounds that negatively impact $P$. brassicae caterpillar performance in Arabidopsis supports this conclusion [81, 82]. In addition, since ET is an important regulator associated with $\mathrm{Xcr}$ in Arabidopsis [47], local ET signaling may be involved in the local effect of Xcr on P. brassicae performance. Moreover, plant nutritional quality at the treatment site could also play a role. It may negatively correlate with insect performance on eggtreated sites but positively on Xcr-treated sites. For instance, leaf carbohydrate content was found to be controlled by JA and mediated plant susceptibility to an adapted herbivore in Nicotiana attenuata [83].

\section{Conclusions}

Our transcriptome analysis of B. nigra in response to combined stress treatments revealed that the second stress dominates the transcript signature, although pretreatments clearly impacted how plants resisted an herbivore attack. Measurement of defense-signaling hormones and transcript levels of defense marker genes in response to multiple attack by different stresses do not necessarily predict the plant's defense response in a straightforward fashion. Future studies should include more marker genes representing different steps along the molecular sequence of events. Our results show that under conditions of multiple stress the plant responds highly specifically to each stress combination. Contrasting responses strongly suggest that we need to better integrate responses at different levels of biological organization, to consider local versus distant plant responses within a leaf, and to measure the accumulation of a range of (defense) metabolites determining nutritional quality when trying to correlate plant traits with insect performance.

\section{Methods \\ Biological material}

Seeds of Brassica nigra were collected from a wild population in Wageningen (The Netherlands) [43]. Plants were grown in soil in growth chambers (16 h light, at $25{ }^{\circ} \mathrm{C}$ day, $22{ }^{\circ} \mathrm{C}$ night, $60 \%$ relative humidity) under white fluorescent light $\left(170 \mu \mathrm{mol} \mathrm{m}{ }^{-2} \mathrm{~s}^{-1}\right)$. Seeds were stratified for 3 days at $4{ }^{\circ} \mathrm{C}$ after sowing. The soil contained $65 \%$ humus, $10 \%$ sand, $15 \%$ perlite and $10 \%$ silt. Growth conditions were the same in the different bioassays described below.

Xanthomonas campestris pv. raphani (Xcr) (formerly classified as $X$. campestris pv. armoraciae) was obtained from the Plant-Microbe Interactions group of Utrecht University (The Netherlands) and was originally acquired from the Department of Plant Pathology at Ohio State University (USA). The pathovar identity was confirmed by pathogenicity assays and PCR. Bacteria were grown in $10 \mathrm{ml}$ of liquid King B culture medium (20 g / l peptone (Sigma-Aldrich), $1.5 \mathrm{~g} / \mathrm{l}$ dipotassium hydrogen phosphate, $1.5 \mathrm{~g} / \mathrm{l}$ magnesium sulfate heptahydrate, $12 \mathrm{~g} / \mathrm{l}$ agar, at a final $\mathrm{pH}$ of 7.2) supplemented with rifampicin $(25 \mu \mathrm{g} / \mathrm{ml})$ and grown in a shaker at $28{ }^{\circ} \mathrm{C}, 200 \mathrm{rpm}$, during $48 \mathrm{~h}$. Xcr culture was centrifuged at $7000 \mathrm{rpm}$ during $2 \mathrm{~min}$. The supernatant was discarded and the pellet was washed and re-suspended in $10 \mathrm{mM} \mathrm{MgCl} 2$ and centrifuged again at $7000 \mathrm{rpm}$ during $2 \mathrm{~min}$. The supernatant was discarded and the pellet diluted in $10 \mathrm{mM} \mathrm{MgCl}$ and adjusted to an OD 600 of 0.07 to obtain a concentration of $10^{7} \mathrm{cfu} / \mathrm{ml}$.

Pieris brassicae was reared on Brussels sprout plants (Brassica oleracea var. gemmifera) in $1 \mathrm{~m}^{3}$ cages in a greenhouse $\left(25 \pm 5{ }^{\circ} \mathrm{C}, 60 \pm 5 \% \mathrm{RH}, 16 / 8 \mathrm{~h}\right.$ light-dark cycle) at Lausanne University (Switzerland). Eggs were removed manually from the plants and crushed with a pestle in Eppendorf tubes. After centrifugation $\left(15^{\prime} 000 \mathrm{~g}\right.$, $3 \mathrm{~min}$ ), the supernatant (egg extract) was stored at $-20^{\circ} \mathrm{C}$.

Brevicoryne brassicae aphids were reared on $B$. oleracea var. gemmifera in a greenhouse $\left(22 \pm 3{ }^{\circ} \mathrm{C}, 65 \pm 5 \%\right.$ 
$\mathrm{RH}, 16 / 8$ h light-dark cycle) at Wageningen University (The Netherlands), where all experiments with aphids were also performed. $B$. nigra plants were grown in peat soil (Lentse potgrond no. 4, Lent, The Netherlands).

The pest species $P$. brassicae and B. brassicae, and $B$. nigra plants were collected in the wild in The Netherlands. This complies with national legislation as The Netherlands allows free access to its biodiversity under the Nagoya Protocol. Correct identification of B. nigra was confirmed by Dr. E. H. Poelman (Department of Plant Sciences, Wageningen University, The Netherlands). Seeds of B. oleracea var. gemmifera were obtained commercially from Semences Zollinger (1897 Les Evouettes, Switzerland) or Syngenta Seeds (2678 LV De Lier, The Netherlands).

\section{Plant treatments}

The overall experimental design is summarized in Table S4 (Additional file 11: Table S4). Plants were 5 weeks old when exposed to the various treatments. Pretreatments with egg extract and the pathogen were applied to the three youngest fully developed leaves of three plants. Aphids were applied to a single leaf, i.e. the first fully developed leaf (nine plants in total), according to a design that has been used in previous experiments with the same study system [84, 85]. For $P$. brassicae egg-extract treatment, $12 \times 2 \mu \mathrm{l}$ of egg extract were added to each of the three leaves and incubated for $72 \mathrm{~h}$. This treatment was equivalent to treatments previously applied to Arabidopsis and corresponds to approximately $10-12$ egg batches per leaf, each batch consisting of 20-30 eggs [35, 66]. Leaves of untreated plants were used as controls.

For infection with the bacterial pathogen, $X$. campestris pv. raphani, each of the three treatment leaves was subjected to three infiltrations of $10^{7} \mathrm{cfu} / \mathrm{ml}$ using a $1 \mathrm{ml}$ needleless syringe and incubated for $72 \mathrm{~h}$. Each infiltration zone represented a circle of $1.5 \mathrm{~cm}^{2}$. In control plants, the same number of $10 \mathrm{mM} \mathrm{MgCl}$ infiltrations was performed.

For treatment with B. brassicae aphids, 100 nymphs were placed on the youngest fully developed leaf on each of nine plants, which were incubated for $48 \mathrm{~h}$. Aphids were not constrained but remained on the leaf on which they had been introduced.

Treatment with caterpillars consisted of the introduction of 10 neonate caterpillars on the three leaves that had received a pretreatment (combined stresses) or on three leaves similar in development of clean plants. Thirty neonate caterpillars were introduced on the single aphid-treated leaf or a single leaf of clean plant. Caterpillars were allowed to feed for $24 \mathrm{~h}$.

All experiments were repeated independently five or more times at intervals of several weeks.
Insect performance assays on plants pretreated with egg extract or pathogen

Five-week-old $B$. nigra plants were placed in $60 \times 60 \times 60 \mathrm{~cm}$ plastic tents (Bugdorm company) in a growth chamber $\left(20 \pm 1{ }^{\circ} \mathrm{C}, 65 \pm 10 \%\right.$ relative humidity, $10 / 14 \mathrm{~h}$ light-dark cycle, $100 \mu \mathrm{mol} \mathrm{m}{ }^{-2} \mathrm{~s}^{-1}$ ). For insect bioassays performed on entire leaves, ten neonate caterpillars were placed on each of the three pretreated leaves or on three leaves of clean plants with a total of 30 caterpillars per plant. Caterpillar weight was measured after 7 days of feeding. For bioassays investigating local vs. distal effects of pretreatment, five neonate caterpillars were placed in a clip cage $(36.5 \times 25.4 \times 9.5 \mathrm{~mm}$, BioQuip Products, USA) on each of three pretreated leaves with a total of 15 larvae per plant either at the same site or a site distal from where the pretreatment was applied. Plants were pretreated as described above with egg extract or the pathogen and incubated for 3 days (see Fig. 4a for experimental design). Caterpillar weight was measured after 4 days. For all experiments, insect recovery was similar between treatments.

Each treatment was done on three different plants for each biological replicate. All experiments were repeated independently three or more times at intervals of several weeks.

\section{Hormone and glucosinolate analysis}

Leaf tissues that were sampled for hormone (SA and JA) and GS analysis were exposed to egg extract, the pathogen, and/or caterpillar feeding as described above. Entire leaves (experiments with no constraint on caterpillar feeding) or $2.4 \mathrm{~cm}$ leaf discs (experiments with constrained caterpillar feeding) were harvested and frozen in liquid nitrogen. Extraction, UHPLC-QTOFMS measurement and data analysis were conducted as described earlier [86, 87]. Three independent biological replicates were analyzed for each treatment.

\section{Transcriptome analyses}

Following treatment, entire leaves were harvested, flashfrozen in liquid nitrogen and stored at $-80{ }^{\circ} \mathrm{C}$. RNA extraction, probe labeling, hybridization onto Arabidopsis CATMAv4 microarrays, and data analyses have been published previously [51, 56, 88]. For data analysis, we used an expression threshold of $\log _{2}>0.585$ and $<-0.585$, and an unadjusted $P$-value of 0.05 . FDR values are shown in supplementary data for further evaluation. GO enrichment analysis was performed with AgriGO singular enrichment analysis using hypergeometric test [89].

\section{Quantitative PCR}

Relative gene expression was measured according to previously published procedures [35, 90]. Briefly, 500 
nanograms of total RNA were transcribed to cDNA using M-MLV reverse transcriptase (Invitrogen) and oligo dT primers according to commercial instructions. cDNA synthesis was done in triplicates. QPCR analysis was performed in a final volume of $25 \mu \mathrm{l}$ according to the Brilliant III Fast SYBR Green instruction manual (Agilent). B. nigra primers (Additional file 12: Table S5) were designed on conserved sequences identified by multiple alignments of genes from different species of the Brassica family. Sequences were obtained from the Brassica database (http://brassica.nbi.ac.uk/BrassicaDB/). Each primer has a Tm of $60{ }^{\circ} \mathrm{C}$ and gives an amplicons length between 100 and $250 \mathrm{bp}$ in the conserved part of the cDNA strand. Primer efficiencies were evaluated by five-step dilution regression. Each amplicon produced a single band and was confirmed by Sanger sequencing. For normalization, the BnSAND gene was used as housekeeping gene. Similar to Arabidopsis SAND gene [91], its expression was stable across experiments.

\section{Additional files}

Additional file 1: Table S1. Gene expression ratios $\left(\log _{2}\right)$ for all biological replicates. (XLSX $16429 \mathrm{~kb}$ )

Additional file 2: Table S2. GO analysis of $P$. brassicae-regulated genes. (PDF $49 \mathrm{~kb}$ )

Additional file 3: Figure S1. Expression of the top-50 upregulated genes in response to $P$. brassicae feeding and combined stresses. The highest significantly upregulated genes $\left(\log _{2}>0.585, P<0.05\right)$ were extracted from microarray data (orange bars) and plotted with values from combined stresses. (A) Egg extract/P. brassicae larvae (yellow bars), (B) Xanthomonas campestris pv. raphani/P. brassicae larvae (green bars), and (C) Brevicoryne brassicae/P. brassicae larvae (blue bars). Significant differences between single and combined stress are indicated (Student's $t$-test, $\left.{ }^{* * *} p<0.001,{ }^{* *} p<0.01,{ }^{*} P<0.05\right)$. (PDF $\left.1871 \mathrm{~kb}\right)$

Additional file 4: Figure S2. Expression of the top-50 downregulated genes in response to $P$. brassicae feeding and combined stresses. The highest significantly downregulated genes $\left(\log _{2}<-0.585, P<0.05\right)$ were extracted from microarray data (orange bars) and plotted with values from combined stresses. (A) Egg extract/P. brassicae larvae (yellow bars), (B) Xanthomonas campestris pv. raphani/P. brassicae larvae (green bars), and (C) Brevicoryne brassicae/P. brassicae larvae (blue bars). Significant differences between single and combined stress are indicated (Student's t-test, $\left.{ }^{* *} P<0.001,{ }^{* *} P<0.01,{ }^{*} P<0.05\right)$. (PDF $1875 \mathrm{~kb}$ )

Additional file 5: Figure S3. GO analysis of genes specifically upregulated by combined stress. GO terms significantly enriched with each combined stress are shown separately. Length of the bars shows the percentage of regulated genes in the respective $\mathrm{GO}$ categories. (PDF $951 \mathrm{~kb}$ )

Additional file 6: Figure S4. GO analysis of genes specifically downregulated by combined stress. GO analysis of genes specifically downregulated by combined stress. GO terms significantly enriched with each combined stress are shown separately. Length of the bars shows the percentage of regulated genes in the respective GO categories. (PDF $918 \mathrm{~kb}$ )

Additional file 7: Figure S5. Quantification of defense signals and glucosinolates. (A) Experimental design. (B) Quantification of jasmonic acid (JA), salicylic acid (SA) and total glucosinolates (GS) in single and combined stress in whole 5-week-old $B$. nigra leaves. Plants were pretreated for 3 days with P. brassicae egg extract (EE) or Xanthomonas campestris pv. raphani $(X \mathrm{Cr})$ and further challenged with $P$. brassicae $(\mathrm{P})$ larvae for $24 \mathrm{~h}$. Controls (CTL) consisted of untreated plants or plants exposed to a single treatment. Values $( \pm \mathrm{SE}$ ) are the mean of three independent experiments. Letters indicate significant difference between treatments (two-way ANOVA followed by Tukey's honest significant difference test, $P<0.05$ ). (PDF $1050 \mathrm{~kb}$ )

Additional file 8: Table S3. Glucosinolate content in B. nigra leaves. (PDF $37 \mathrm{~kb}$ )

Additional file 9: Figure S6. Expression of glucosinolate biosynthesis genes in response to $P$. brassicae feeding and combined stresses. Values were extracted from microarray data. P. brassicae larvae (orange bars), egg extract/P. brassicae larvae (yellow bars), Xanthomonas campestris pv. raphani/P. brassicae (green bars), Brevicoryne brassicae/P. brassicae (blue bars). Significant differences between single and combined stress are indicated (Student's $t$-test, ${ }^{* * *} P<0.001$, ${ }^{* *} P<0.01$, ${ }^{*} P<0.05$ ).

(PDF $982 \mathrm{~kb}$ )

Additional file 10: Figure S7. Feeding behavior of $P$. brassicae larvae in response to combined stresses. Neonate larvae were allowed to feed freely for 2 days ( $P$. brassicae) on 5-week-old B. nigra plants pretreated for 3 days with egg extract (A) or Xanthomonas campestris pv. raphani (B). Representative images from three biological replicates are shown. Scale bar $=1 \mathrm{~cm}$. (PDF $9284 \mathrm{~kb}$ )

Additional file 11: Table S4. Overall experimental design. (PDF $48 \mathrm{~kb}$ )

Additional file 12: Table S5. List of primers used for QPCR. (PDF 51 kb)

Acknowledgements

We thank Blaise Tissot for maintenance of the plants and Johann Weber for help with microarray analyses.

\section{Funding}

The Swiss National Science Foundation (grant 31003A_149286 and EUROCORES program EuroVOL grant 31VL30_134414 to PR) and the Earth and Life Sciences Council (ALW) of the Netherlands Organisation for Scientific Research (NWO) (EUROCORES program EuroVOL grant 855.01.171 to MD) supported this work

Availability of data and materials

Microarray data have been submitted to the ArrayExpress database (www.ebi.ac.uk/arrayexpress) under accession number E-MTAB-5059.

\section{Authors' contributions}

$C B, C P, R G, M D$ and $P R$ designed the experiments. $C B, S L$ and $C P$ performed the experiments. $C B$ and $P R$ analyzed the data. $C B, M D, R G$ and $P R$ wrote the paper. All authors have read and approved this manuscript.

Ethics approval and consent to participate

Not applicable.

\section{Consent for publication}

Not applicable.

\section{Competing interests}

The authors declare that they have no competing interests.

\section{Publisher's Note}

Springer Nature remains neutral with regard to jurisdictional claims in published maps and institutional affiliations.

\section{Author details}

${ }^{1}$ Department of Plant Molecular Biology, University of Lausanne, Biophore Building, 1015 Lausanne, Switzerland. 'Laboratory of Entomology,

Wageningen University, P.O. Box 16, 6700 AA Wageningen, The Netherlands.

Received: 6 January 2017 Accepted: 10 July 2017

Published online: 17 July 2017

References

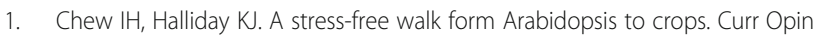
Biotechnol. 2011:22:281-6.

2. Bray EA. Plant responses to water deficit. Trends Plant Sci. 1997;2:48-54. 
3. Howe GA, Jander G. Plant immunity to insect herbivores. Annu Rev Plant Biol. 2008;59:41-66.

4. Dean R, van Kan JAL, Pretorius ZA, Hammond-Kosack KE, et al. The top 10 fungal pathogens in molecular plant pathology. Mol Plant Pathol. 2012;13:414-30.

5. Xin X-F, He SY. Pseudomonas syringae pv. tomato DC3000: a model pathogen for probing disease susceptibility and hormone signaling in plants. Annu Rev Phytopathol. 2013;51:473-98.

6. Atkinson NJ, Urwin PE. The interaction of plant biotic and abiotic stresses: from genes to the field. J Exp Bot. 2012;63:3523-43.

7. Rejeb IB, Pastor V, Mauch-Mani B. Plant responses to simultaneous biotic and abiotic stress: molecular mechanisms. Plants. 2014;3:458-75.

8. Suzuki N, Rivero RM, Shulaev V, Blumwald E, Mittler R. Abiotic and biotic stress combinations. New Phytol. 2014;203:32-43.

9. Ramegowda V, Senthil-Kumar M. The interactive effects of simultaneous biotic and abiotic stresses on plants: mechanistic understanding from drought and pathogen combination. J Plant Physiol. 2015;176:47-54.

10. Ahuja I, de Vos RCH, Bones AM, Hall RD. Plant molecular stress responses face climate change. Trends Plant Sci. 2010;15:664-74.

11. Schoonhoven LM, van Loon JJA, Dicke M. Insect-plant biology. USA: Oxford University Press; 2005.

12. Huberty AF, Denno RF. Plant water stress and its consequences for herbivorous insects: a new synthesis. Ecology. 2004;85:1383-98.

13. Mewis I, Khan MAM, Glawischnig E, Schreiner M, Ulrichs C. Water stress and aphid feeding differentially influence metabolite composition in Arabidopsis thaliana L. PLoS One. 2012;7:e48661.

14. Chakraborty S, Whitehill J, Hill AL, Opiyo SO, Cipollini D, Herms DA, Bonello P. Effects of water availability on emerald ash borer larval performance and phloem phenolics of Manchurian and black ash. Plant Cell Environ. 2014;37:1009-21.

15. Rivas-Ubach A, Gargallo-Garriga A, Sardans J, Oravec M, Mateu-Castell L, Pérez-Trujillo M, Parella T, Ogaya R, Urban O, Peñuelas J. Drought enhances folivory by shifting foliar metabolomes in Quercus ilex trees. New Phytol. 2014:202:874-85.

16. Nguyen D, D'Agostino N, Tytgat TOG, et al. Drought and flooding have distinct effects on herbivore-induced responses and resistance in Solanum dulcamara. Plant Cell Environ. 2016;39:1485-99.

17. Khan GA, Vogiatzaki E, Glauser G, Poirier Y. Phosphate deficiency induces the jasmonate pathway and enhances resistance to insect herbivory. Plant Physiol. 2016;171:632-44

18. Tack AJM, Dicke M. Plant pathogens structure arthropod communities across multiple spatial and temporal scales. Funct Ecol. 2013;27:633-45.

19. Lazebnik J, Frago E, Dicke M, van Loon JJA. Phytohormone mediation of interactions between herbivores and plant pathogens. J Chem Ecol. 2014; 40:730-41.

20. Stout MJ, Thaler JS, Thomma BPHJ. Plant-mediated interactions between pathogenic microorganisms and herbivorous arthropods. Annu Rev Entomol. 2006;51:663-89.

21. Naemi Al F, Hatcher PE. Contrasting effects of necrotrophic and biotrophic plant pathogens on the aphid Aphis fabae. Entomol Exp Appli. 2013;148: 234-45

22. Davila Olivas NH, Coolen S, Huang P, et al. Effect of prior drought and pathogen stress on Arabidopsis transcriptome changes to caterpillar herbivory. New Phytol. 2016;210:1344-56.

23. Thaler JS, Agrawal AA, Halitschke R. Salicylate-mediated interactions between pathogens and herbivores. Ecology. 2010;91:1075-82.

24. Heidel AJ, Barazani O, Baldwin IT. Interaction between herbivore defense and microbial signaling: bacterial quorum-sensing compounds weaken JA-mediated herbivore resistance in Nicotiana attenuata. Chemoecol. 2010;20:149-54.

25. Hilfiker O, Groux R, Bruessow F, Kiefer K, Zeier J, Reymond P. Insect eggs induce a systemic acquired resistance in Arabidopsis. Plant J. 2014;80:1085-94.

26. Pieterse CMJ, der Does VD, Zamioudis C, Leon-Reyes A, Van Wees SCM. Hormonal modulation of plant immunity. Annu Rev Cell Dev Biol. 2012;28: 489-521.

27. Reymond P, Farmer EE. Jasmonate and salicylate as global signals for defense gene expression. Curr Opin Plant Biol. 1998;1:404-11.

28. Spoel SH, Dong X. Making sense of hormone crosstalk during plant immune responses. Cell Host Microbe. 2008:3:348-51.

29. Zarate SI, Kempema LA, Walling LL. Silverleaf whitefly induces salicylic acid defenses and suppresses effectual jasmonic acid defenses. Plant Physiol. 2007; 143:866-75.

30. Koornneef A, Pieterse CMJ. Cross talk in defense signaling. Plant Physiol. 2008;146:839-44
31. Zhang PJ, Zheng SJ, van Loon JJA, Boland W, David A, Mumm R, Dicke M. Whiteflies interfere with indirect plant defense against spider mites in lima bean. Proc Nat Acad Sci USA. 2009;106:21202-7.

32. Zhang PJ, Broekgaarden C, Zheng SJ, Snoeren TAL, van Loon JJA, Gols R, Dicke M. Jasmonate and ethylene signaling mediate whitefly-induced interference with indirect plant defense in Arabidopsis thaliana. New Phytol. 2013;197:1291-9.

33. Caarls L, Pieterse CMJ, Van Wees SCM. How salicylic acid takes transcriptional control over jasmonic acid signaling. Frontiers Plant Sci. 2015; 6:170.

34. Cipollini DD, Enright SS, Traw MBM, Bergelson JJ. Salicylic acid inhibits jasmonic acid-induced resistance of Arabidopsis thaliana to Spodoptera exigua. Mol Ecol. 2004;13:1643-53.

35. Bruessow F, Gouhier-Darimont C, Buchala A, Metraux J-P, Reymond P. Insect eggs suppress plant defence against chewing herbivores. Plant J. 2010;62: 876-85

36. Koornneef A, Leon-Reyes A, Ritsema T, Verhage A, Otter Den FC, Van Loon LC, Pieterse CMJ. Kinetics of salicylate-mediated suppression of jasmonate signaling reveal a role for redox modulation. Plant Physiol. 2008;147:1358-68.

37. Leon-Reyes A, Spoel SH, De Lange ES, Abe H, Kobayashi M, Tsuda S, Millenaar FF, Welschen RAM, Ritsema T, Pieterse CMJ. Ethylene modulates the role of NONEXPRESSOR OF PATHOGENESIS-RELATED GENES1 in cross talk between salicylate and jasmonate signaling. Plant Physiol. 2009;149: 1797-809.

38. Rasmussen $S$, Barah $P$, Suarez-Rodriguez MC, Bressendorff S, Friis $P$, Costantino P, Bones AM, Nielsen HB, Mundy J. Transcriptome responses to combinations of stresses in Arabidopsis. Plant Physiol. 2013;161:1783-94.

39. Voelckel C, Baldwin IT. Generalist and specialist lepidopteran larvae elicit different transcriptional responses in Nicotiana attenuata, which correlate with larval FAC profiles. Ecol Lett. 2004;7:770-5.

40. Rizhsky L, Liang H, Shuman J, Shulaev V, Davletova S, Mittler R. When defense pathways collide. The response of Arabidopsis to a combination of drought and heat stress. Plant Physiol. 2004;134:1683-96.

41. Atkinson NJ, Lilley CJ, Urwin PE. Identification of genes involved in the response of Arabidopsis to simultaneous biotic and abiotic stresses. Plant Physiol. 2013;162:2028-41.

42. Westman AL, Kresovich S, Dickson MH. Regional variation in Brassica nigra and other weedy crucifers for disease reaction to Alternaria brassicicola and Xanthomonas campestris pv. campestris. Euphytica. 1999;106:253-9.

43. Pashalidou FG, Fatouros NE, van Loon JJA, Dicke M, Gols R. Plant-mediated effects of butterfly egg deposition on subsequent caterpillar and pupal development, across different species of wild Brassicaceae. Ecol Entomol. 2015:40:444-50

44. Moran PJ, Thompson GA. Molecular responses to aphid feeding in Arabidopsis in relation to plant defense pathways. Plant Physiol. 2001;125: 1074-85.

45. de Vos M, Van Oosten VR, Van Poecke RMP, et al. Signal signature and transcriptome changes of Arabidopsis during pathogen and insect attack. Mol Plant-Microbe Interact. 2005;18:923-37.

46. Gouhier-Darimont C, Schmiesing A, Bonnet C, Lassueur S, Reymond P. Signalling of Arabidopsis thaliana response to Pieris brassicae eggs shares similarities with PAMP-triggered immunity. J Exp Bot. 2013;64:665-74.

47. Ton J, Van Pelt JA, Van Loon LC, Pieterse CMJ. Differential effectiveness of salicylate-dependent and jasmonate/ethylene-dependent induced resistance in Arabidopsis. Mol Plant-Microbe Interact. 2002;15:27-34.

48. Lucas-Barbosa D, van Loon JJA, Gols R, van Beek TA, Dicke M. Reproductive escape: annual plant responds to butterfly eggs by accelerating seed production. Funct Ecol. 2013;27:245-54.

49. Lucas-Barbosa D, Dicke M, Kranenburg T, Aartsma Y, Huigens ME, van Beek TA, van Loon JJA. Endure and call for help: strategies of black mustard plants to deal with a specialised caterpillar. Funct Ecol. 2017;31:325-33.

50. Hilson P, Allemeersch J, Altmann T, et al. Versatile gene-specific sequence tags for Arabidopsis functional genomics: transcript profiling and reverse genetics applications. Genome Res. 2004;14:2176-89.

51. Sclep G, Allemeersch J, Liechti R, et al. CATMA, a comprehensive genomescale resource for silencing and transcript profiling of Arabidopsis genes. BMC Bioinfo. 2007:8:400.

52. Broekgaarden C, Poelman EH, Steenhuis G, Voorrips RE, Dicke M, Vosman B. Responses of Brassica oleracea cultivars to infestation by the aphid Brevicoryne brassicae: an ecological and molecular approach. Plant Cell Environ. 2008;31:1592-605. 
53. Broekgaarden C, Voorrips RE, Dicke M, Vosman B. Transcriptional responses of Brassica nigra to feeding by specialist insects of different feeding guilds. Insect Sci. 2011;18:259-72.

54. Reymond P, Weber H, Damond M, Farmer EE. Differential gene expression in response to mechanical wounding and insect feeding in Arabidopsis. Plant Cell. 2000;12:707-20.

55. Voelckel C, Baldwin IT. Herbivore-induced plant vaccination. Part II. Arraystudies reveal the transience of herbivore-specific transcriptional imprints and a distinct imprint from stress combinations. Plant J. 2004;38:650-63.

56. Reymond P, Bodenhausen N, Van Poecke RMP, Krishnamurthy V, Dicke M Farmer EE. A conserved transcript pattern in response to a specialist and a generalist herbivore. Plant Cell. 2004;16:3132-47.

57. Major IT, Constabel CP. Molecular analysis of poplar defense against herbivory: comparison of wound- and insect elicitor-induced gene expression. New Phytol. 2006;172:617-35.

58. Broekgaarden C, Poelman EH, Steenhuis G, Voorrips RE, Dicke M, Vosman B. Genotypic variation in genome-wide transcription profiles induced by insect feeding: Brassica oleracea-Pieris rapae interactions. BMC Genomics. 2007;8:239

59. Coolen S, Proietti S, Hickman R, et al. Transcriptome dynamics of Arabidopsis during sequential biotic and abiotic stresses. Plant J. 2016;86:249-67.

60. Kliebenstein DJ, Kroymann J, Mitchell-Olds T. The glucosinolate-myrosinase system in an ecological and evolutionary context. Curr Opin Plant Biol. 2005:8:264-71.

61. Halkier BA, Gershenzon J. Biology and biochemistry of glucosinolates. Annu Rev Plant Biol. 2006:57:303-33.

62. Gigolashvili T, Yatusevich R, Berger B, Müller C, Flügge U-I. The R2R3-MYB transcription factor HAG1/MYB28 is a regulator of methionine-derived glucosinolate biosynthesis in Arabidopsis thaliana. Plant J. 2007;51:247-61.

63. Kos M, Houshyani B, Wietsma R, Kabouw P, Vet LEM, van Loon JJA, Dicke M. Effects of glucosinolates on a generalist and specialist leaf-chewing herbivore and an associated parasitoid. Phytochemistry. 2012;77:162-70.

64. Schweizer F, Fernández-Calvo P, Zander M, Diez-Diaz M, Fonseca S, Glauser G Lewsey MG, Ecker JR, Solano R, Reymond P. Arabidopsis basic helix-loop-helix transcription factors MYC2, MYC3, and MYC4 regulate glucosinolate biosynthesis, insect performance, and feeding behavior. Plant Cell. 2013;25:3117-32.

65. Köhler A, Maag D, Veyrat N, Glauser G, Wolfender J-L, Turlings TCJ, Erb M. Within-plant distribution of 1,4-benzoxazin-3-ones contributes to herbivore niche differentiation in maize. Plant Cell Environ. 2015;38:1081-93.

66. Little D, Gouhier-Darimont C, Bruessow F, Reymond P. Oviposition by pierid butterflies triggers defense responses in Arabidopsis. Plant Physiol. 2007;143: 784-800.

67. Firtzlaff V, Oberländer J, Geiselhardt S, Hilker M, Kunze R. Pre-exposure of Arabidopsis to the abiotic or biotic environmental stimuli "chilling" or "insect eggs" exhibits different transcriptomic responses to herbivory. Sci Rep. 2016;6:28544.

68. Ponzio C, Papazian S, Albrectsen BR, Dicke M, Gols R. Dual herbivore attack and herbivore density affect metabolic profiles of Brassica nigra leaves, Plant Cell Environ., in press. doi:10.1111/pce.12926

69. Smallegange RC, van Loon JJA, Blatt SE, Harvey JA, Agerbirk N, Dicke M. Flower vs. leaf feeding by Pieris brassicae: glucosinolate-rich flower tissues are preferred and sustain higher growth rate. J Chem Ecol. 2007;33:1831-44.

70. Mur LAJ, Kenton P, Atzorn R, Miersch O, Wasternack C. The outcomes of concentration-specific interactions between salicylate and jasmonate signaling include synergy, antagonism, and oxidative stress leading to cell death. Plant Physiol. 2006;140:249-62.

71. Appel HM, Fescemyer H, Ehlting J, Weston D, Rehrig E, Joshi T, Xu D, Bohlmann J, Schultz J. Transcriptional responses of Arabidopsis thaliana to chewing and sucking insect herbivores. Front Plant Sci. 2014;5:565.

72. Pashalidou FG, Lucas-Barbosa D, van Loon J, Dicke M, Fatouros N. Phenotypic plasticity of plant response to herbivore eggs: effects on resistance to caterpillars and plant development. Ecology. 2012;94:702-13.

73. Geiselhardt S, Yoneya K, Blenn B, Drechsler N, Gershenzon J, Kunze R, Hilker M. Egg laying of cabbage white butterfly. (Pieris brassicae) on Arabidopsis thaliana affects subsequent performance of the larvae. PLoS One. 2013;8:e59661

74. Pashalidou FG, Frago E, Griese E, Poelman EH, van Loon JJA, Dicke M, Fatouros NE. Early herbivore alert matters: plant-mediated effects of egg deposition on higher trophic levels benefit plant fitness. Ecol Lett. 2015;18:927-36.

75. Schmiesing A, Emonet A, Gouhier-Darimont C, Reymond P. Arabidopsis MYC transcription factors are the target of hormonal SA/JA cross talk in response to Pieris brassicae egg extract. Plant Physiol. 2016;170:2432-43.
76. Cardoza YJ, Tumlinson JH. Compatible and incompatible Xanthomonas infections differentially affect herbivore-induced volatile emission by pepper plants. J Chem Ecol. 2006;32:1755-68.

77. Ponzio C, Weldegergis BT, Dicke M, Gols R. Compatible and incompatible pathogen-plant interactions differentially affect plant volatile emissions and the attraction of parasitoid wasps. Funct Ecol. 2016;30:1779-89.

78. Perkins LE, Cribb BW, Brewer PB, Hanan J, Grant M, de Torres M, Zalucki MP. Generalist insects behave in a jasmonate-dependent manner on their host plants, leaving induced areas quickly and staying longer on distant parts. Proc Royal Soc London B. 2013;280:20122646.

79. Khaling E, Papazian S, Poelman EH, Holopainen JK, Albrectsen BR, Blande JD. Ozone affects growth and development of Pieris brassicae on the wild host plant Brassica nigra. Environ Poll. 2015;199:119-29.

80. Poelman EH, Galiart RJFH, Raaijmakers CE, van Loon JJA, van Dam NM. Performance of specialist and generalist herbivores feeding on cabbage cultivars is not explained by glucosinolate profiles. Entomol Exp Appli. 2008; 127:218-28.

81. Onkokesung N, Reichelt M, van Doorn A, Schuurink RC, van Loon JJA, Dicke M. Modulation of flavonoid metabolites in Arabidopsis thaliana through overexpression of the MYB75 transcription factor: role of kaempferol-3,7dirhamnoside in resistance to the specialist insect herbivore Pieris Brassicae. J Exp Bot. 2014:65:2203-17.

82. Onkokesung N, Reichelt M, van Doorn A, Schuurink RC, Dicke M. Differential costs of two distinct resistance mechanisms induced by different herbivore species in Arabidopsis. Plant Physiol. 2016;170:891-906.

83. Machado RAR, Arce CCM, Ferrieri AP, Baldwin IT, Erb M. Jasmonatedependent depletion of soluble sugars compromises plant resistance to Manduca sexta. New Phytol. 2015;207:91-105.

84. Ponzio C, Gols R, Weldegergis BT, Dicke M. Caterpillar-induced plant volatiles remain a reliable signal for foraging wasps during dual attack with a plant pathogen or non-host insect herbivore. Plant Cell Environ. 2014;37: 1924-35.

85. Ponzio C, Cascone P, Cusumano A, Weldegergis BT, Fatouros NE, Guerrieri E, Dicke M, Gols R. Volatile-mediated foraging behaviour of three parasitoid species under conditions of dual insect herbivore attack. Animal Behav. 2016;111:197-206

86. Glauser G, Schweizer F, Turlings TCJ, Reymond P. Rapid profiling of intact glucosinolates in Arabidopsis leaves by UHPLC-QTOFMS using a charged surface hybrid column. Phytochem Anal. 2012;23:520-8.

87. Glauser G, Vallat A, Balmer D. 2014. Hormone profiling. Methods Mol Biol 2014;1062:597-608.

88. Papazian S, Khaling E, Bonnet C, Lassueur S, Reymond P, Moritz T, Blande JD, Albrectsen BR. Central metabolic responses to ozone and herbivory affect photosynthesis and stomatal closure. Plant Physiol. 2016;172:2057-78.

89. Du Z, Zhou X, Ling Y, Zhang Z, Su Z. agriGO: a GO analysis toolkit for the agricultural community. Nucl Acids Res. 2010;38:W64-70.

90. Consales F, Schweizer F, Erb M, Gouhier-Darimont C, Bodenhausen N, Bruessow F, Sohby I, Reymond P. Insect oral secretions suppress woundinduced responses in Arabidopsis. J Exp Bot. 2012;63:727-37.

91. Czechowski T, Stitt M, Altmann T, Udvardi MK, Scheible WR. Genome-wide identification and testing of superior reference genes for transcript normalization in Arabidopsis. Plant Physiol. 2005;139:5-17.

\section{Submit your next manuscript to BioMed Central and we will help you at every step:}

- We accept pre-submission inquiries

- Our selector tool helps you to find the most relevant journal

- We provide round the clock customer support

- Convenient online submission

- Thorough peer review

- Inclusion in PubMed and all major indexing services

- Maximum visibility for your research

Submit your manuscript at www.biomedcentral.com/submit 